\title{
THE CONNECTION BETWEEN DIFFERENT NEUROTRANSMITTERS INVOLVED IN COGNITIVE PROCESSES
}

\author{
CLAUDIA HANDRA ${ }^{1}$, OANA ANDREIA COMAN ${ }^{2}$, LAURENTTIU COMAN ${ }^{3}$, TUDOR ENACHE $^{4}$, \\ SMARANDA STOLERU ${ }^{2}$, ADELINA-MIHAELA SORESCU ${ }^{2}$, ISABEL GHIȚÄ ${ }^{2 *}$, ION FULGA ${ }^{2}$ \\ ${ }^{I}$ Department of Work Medicine, Faculty of Medicine, Carol Davila University of Medicine and Pharmacy, Bucharest, Romania \\ ${ }^{2}$ Department of Pharmacology and Pharmacotherapy, Faculty of Medicine, Carol Davila University of Medicine and Pharmacy, \\ Bucharest, Romania \\ ${ }^{3}$ Department of Physiology, Faculty of Pharmacy, Carol Davila University of Medicine and Pharmacy, Bucharest, Romania \\ ${ }^{4}$ Department of Physiology, Faculty of Medicine, Carol Davila University of Medicine and Pharmacy, Bucharest, Romania
}

*corresponding author: isabelghita@yahoo.co.uk

Manuscript received: July 2018

\begin{abstract}
Memory is one of the most complex cognitive functions. Conventionally, one the most important neurotransmitter system implicated in its regulation is the cholinergic system. However, literature certifies that other substances can be associated with certain memory processes as well, for example, the dopaminergic system, the NMDA receptors and the serotoninergic receptors, either direct, or by forming receptor complexes. Aside from these, the adrenergic system has been proven to work synergistically with the cholinergic system. Proving the interaction between nicotine and other neurotransmitters, as well as their involvement in cognition, opened a number of therapeutic possibilities for degenerative diseases such as Alzheimer's disease, Parkinson's disease and schizophrenia. That is to say, future research needs to focus on the potential therapies using these interactions.
\end{abstract}

\section{Rezumat}

Memoria este una din cele mai complexe funcții cognitive. Este unanim acceptat faptul că unul din cele mai importante sisteme de neurotransmițători implicați în reglarea acesteia este sistemul colinergic. Totuși, literatura atestă faptul că și alte substanțe pot fi asociate cu anumite procese ale memoriei, de exemplu sistemul dopaminergic, receptorii NMDA și sistemul serotoninergic, fie direct, sau indirect prin formare de complexe de receptori. În afara acestora, s-a dovedit că sistemul adrenergic acționează sinergic cu cel colinergic. Demonstrarea interacțiunii dintre nicotină şi alţi neurotransmiţători, dar şi implicarea acestora în procesele cognitive, a deschis numeroase posibilități terapeutice pentru tratamentul bolilor neurodegenerative precum boala Alzheimer, boala Parkinson și schizofrenie. Studii ulterioare trebuie să fie centrate pe potențialul terapeutic al acestor interacțiuni.

Keywords: nicotine, memory, neurotransmitters

\section{Introduction}

Memory is an elaborate and intricate cognitive function [10]. During the past decades, it has been well established that a large number of factors are involved in memory formation and consolidation. Research on memory modulation investigates the neurobiological processes and systems that contribute to observed differences in the strength of learning mechanisms and memory functions. Extensive evidence from both animal and human research indicates that emotionally significant experiences activate neurotransmitter systems that regulate the consolidation of newly acquired memories.

For retaining certain pieces of information, complex cognitive processes are necessary. Research over the years proved that every cognitive aspect is mediated and regulated by chemical agents. This is where neurotransmitters are involved.
Learning and memory are, of course, derived from experience-induced changes in behaviour. There is now extensive evidence that administration of central nervous system stimulants enhance memory when administered shortly after training [72]. Such findings provide strong evidence that the treatments enhance memory by modulating memory consolidation processes [20].

Nicotine is one of the main substances associated with both learning and memory. The prevailing theory published in literature postulates that nicotine has an enhancing effect on cognition [58, 68]. For example, even by using a partial nicotinic agonists, we can see its effects on memory [16]. Speaking about the action mechanism of the cholinergic system, two pathways have been connected to memory modulation. That is to say, nicotine can exert its effects on memory either in a direct manner, through its receptor subtypes (the $\alpha 7$ and $\alpha 4 \beta 2$ nicotinic receptors) or indirect, 
working alongside and through other neurotransmitter systems. Literature certifies that other substances that can be associated with certain memory processes as well are the dopaminergic system [4, 15, 34], the NMDA receptors $[1,40]$ and the serotoninergic receptors $[41,74]$.

\section{The adrenergic system in memory}

Catecholamines, including dopamine and norepinephrine, are the main neurotransmitters that mediate a variety of central nervous system (CNS) functions, such as motor control, cognition, emotion, memory processing, and endocrine modulation, determined by recent molecular genetic approaches in mice. Dysfunctions regarding their neurotransmission are involved in some neurologic and neuropsychiatric disorders. As literature suggests, norepinephrine is a key component of the consolidation processes of long-term memory. That is to say that this substance can modulate the neuronal activity in the amygdale as well as the cerebral cortex, in order to condition learning. These effects would not be possible if it were not for the adrenergic receptors.

In 1976, Fulginiti designed an experiment, trying to determine whether the adrenergic receptors were involved in certain cognitive processes [26]. By blocking the noradrenaline synthesis, the authors observed an impairment of the retention phase of memory. Moreover, the authors established the fact that noradrenaline, is not only necessary during the first steps of memory formation, but during the consolidation processes as well, its effects being observed for two hours after training.

The adrenergic receptors are a number of membranebound proteins, linked with regulatory $G$ proteins. Three types of receptors have been studied, $\alpha 1, \alpha 2$ and $\beta$-receptors, each presenting receptor subtypes. Having different action mechanisms, each receptor mediates certain roles of adrenaline and noradrenaline [79]. Speaking about cognition, numerous studies revealed that the memory enhancement effects of the adrenergic system are mediated especially by $\beta$ adrenergic receptors (Table I) [12, 21, 46, 64, 82, 86, 89].

From the studies we assessed, only two of them suggested the potential involvement of $\alpha 2$-adrenergic receptors. While Norozpour only acknowledged only a potential memory augmentation effect of these receptors [61], Torkaman-Boutorabi, by stimulating the medial prefrontal cortex based $\alpha 2$-receptors, displayed the ability to reverse the amnesia induced by morphine administration [80]. However, little is known about the implication of $\alpha 1$-adrenergic receptors. One study showed some significant memory impairment after the down-regulation of this receptor type [9].
When it comes to $\beta$ receptors, evidence to date indicates that their mechanisms have little influence on the working memory functions. Neither systemic administration [3], nor intra-prefrontal cortex infusion [43] of the beta adrenergic antagonist, propranolol, alters working memory performance. More detailed studies with selective beta-1 or beta-2 agents may produce different results, even establishing their role in certain diseases.

Similar to the receptor complexes that form throughout the brain, the adrenergic receptors form such connections as well. Yuan suggest a link between the adrenergic receptors and NMDA receptors [86]. Moreover, there have been studies which observed that the adrenergic system works sinergically with the nicotinic system [45]. By activating the $\alpha 7$ nicotinic receptors subtype, located on postganglionic sympathetic nerve terminals, noradrenaline is released. This cascade may influence memory processes. Still, little is known about these receptor interactions, and future studies need to be performed in order to come to a relevant conclusion. None of these studies would have any importance, if their findings could not be used in developing therapies for different health issues. In recent articles, ADHD symptoms and prefrontal cortex task performance have been improved by administering guanfacine, a known selective $\alpha_{2 \mathrm{~A}}$ agonist $[31,33]$ and is now being tested in other cognitive disorders. However, more extensive research needs to be performed in order to determine how to efficiently modulate these neurotransmitter systems.

\section{The nicotinic and dopaminergic systems in memory}

One of the catecholamine's precursors, dopamine, is a well-represented neurotransmitter in the central nervous system. Ever since its numerous functions have been identified, the dopaminergic system has been vastly discussed in literature. That led to the discovery of a number of different central dopaminergic receptors, each of them mediating specific dopamine actions [31]. Over the years, different classifications have been introduced. Nowadays, there are two main types of dopamine receptors. The first category is represented by the $\mathrm{D}_{1}$-like receptors (including the $D_{1}$ and $D_{2}$ receptors), coupled with the $G_{s}$ protein, while the second type of receptors are represented by the $\mathrm{D}_{2}$-like receptors (including the $\mathrm{D}_{3}, \mathrm{D}_{4}$ and $\mathrm{D}_{5}$ receptors), which are coupled with the $G_{i}$ proteins [56]. Comparing the receptor types, it has been seen that the $D_{1}$ receptor is the most prevailing one, modulating cognitive functions such as memory and learning [15] (Table I).

The role of the dopaminergic system has been heavily studied over the time, especially their interaction with other neurotransmitters. Markett, proved in 2011 the existence of an interaction between the genes involved in the dopaminergic and nicotinic systems. 
FARMACIA, 2019, Vol. 67, 2

That is one example of studies that postulate that the two neurotransmitters are functionally dependent [48]. In a paper published two years later, the same author stated that nicotine, stimulates dopamine's functions, including its cognitive role [12]. However, there have been studies that concluded a negative regulation of the nicotinic system, modulated by the dopaminergic system [36]. Oder studies showed that neither the nicotinic nor the dopaminergic systems determine an improvement of cognitive functions [34]. One study showed that the administration of dopaminergic antagonists blocked the nicotinic modulation of inhibitory avoidance memory [4]. Moreover, the activation of certain nicotinic receptor subtypes increases dopamine levels, thus enhancing memory [79].

Proving both the interaction between the nicotinic and dopaminergic systems as well as their involvement in cognition opened a number of therapeutical prospects for degenerative diseases such as Alzheimer's disease, Parkinson's disease, schizophrenia and others.

Speaking about Alzheimer's disease, certain degrees of dopaminergic dysfunction have been linked to its pathophysiology and can even be used as a predictive factor [50]. In contrast to that, a dopamine precursor, levodopa, has been seen to relieve motor symptoms in Parkinson's disease, but their effect on cognitive dysfunctions has yet to be proven [18]. That is why the use of dopaminergic agonists in cognitive dysfunctions has to further be studied.

\section{The interaction between the cholinergic system and NMDA receptors}

Numerous studies have tried over the years to determine the cognitive modulatory effects of nicotine. While most of them concluded that nicotine induces a positive effect on memory, there have been studies that denied such actions [58]. However, considering the various receptor subtypes and the receptor complexes nicotine tends to form [40], it is safe to say that the nicotinic system has a complex action mechanism.

One other neurotransmitter system that has been previously linked with the cognitive functions is the glutamate NMDA receptor system [51, 44]. In 1991, Izquierdo, with the help of NMDA receptor antagonists (which impaired spatial working memory), concluded that if repeatedly stimulated, this system can regulate cognition. What is more, it was observed that blocking the NMDA receptor induces a resembling degree of memory impairment as the excision of the hippocampus [41].

Different NMDA receptors vary in structure. There are three distinctive subunits, namely GluN1, GluN2, GluN3, that constitute each receptor subtype. Depending on the structural subunits, the receptors have a different activation sequence [81]. NMDA receptors are heterotetramers, their function depending on the two mandatory GluN1 subunits in association with two GluN2 and/or GluN3 subunits. An extracellular amino-terminal domain, an extracellular ligand binding domain (LBD) and an intracellular carboxy-terminal domain assemble the ion channel for sodium and calcium. As the ligand binding site has two domains, the NMDA receptor activation requires the concomitant presence of two ligands.

As we already mentioned, nicotine exerts its effects not only directly, but indirectly as well. It has the potential to influence other receptor systems [1]. Many studies discussed the link between the nicotinic receptors and NMDA receptors. The prevalent conclusion was that the NMDA receptors can be activated by the nicotinic system [85], even though the exact stimulation pattern has yet to be discovered. Li tried to determine in 2013, the nicotine's role inside the $\alpha 7 \mathrm{nAchR}-\mathrm{NMDAR}$ complexes. In spite of the fact that activation of the nicotinic receptors did not seem to increase the ion currents through the NMDA receptor, they did observe that it was required for NMDA's activity. One other theory mentioned in literature is the fact the nicotine can enhance the release of other neurotransmitters, including glutamate [51], thus activating the NMDA receptors (Table I). Regarding the involvement of nicotinic-NMDA receptor complexes in memory, there have been several studies, which tried to corroborate this hypothesis. For example, using a protein (TAT- $\alpha 7$ pep2 [L336-M345]), which interfered with the function of the associated receptors, one study found that even though it did not impair the Morris water maze performance and displaced object recognition in mice, it affected the novel object recognition [44]. Other researchers reported that chronic nicotine use, by stimulating the NMDA receptors, determine an augmentation of long-term potentiation, thus contributing to memory enhancement [85]. However, Levin, concluded in 2003, that inactivation of NMDA, with the help of dizolcipine, lead to a nicotine-induced memory reduction [40]. This lead them to believe that the association between nicotinic and NMDA receptors, blocks nicotine's negative influence on memory.

Even though most studies have been performed on rodents, there have been cases in literature when researchers tried to extrapolate these results in humans. It is a well-known fact that a down-regulation of the nicotinic receptors can be seen in most neurodegenerative diseases [64]. It is also the case of Alzheimer's disease (AD), where not only the nicotinic system is down-regulated, but there is a decrease of NMDA receptors as well [27]. Narahashi tested this affirmation in 2004 and tried to determine whether by stimulating the nicotinic system and/or the NMDA receptors, they can reduce the cognitive alterations present in AD [60]. Similar to other 
studies on this matter, they had positive results, leading us to believe that future research needs to focus on the potential therapies involving the modulation of nicotine-NMDA association.

\section{The nicotinic and serotoninergic systems in cognition}

Serotonin, or 5-hydroxytryptamine (5HT), is synthesized from tryptophan by the enzymes tryptophan-hydroxylase and aromatic-amino-aciddecarboxylase. This substance can bind to 7 receptor types, each having a number of receptor subtypes. Depending on their action mechanism, these receptors can either be serotonin-gated ion channels (for example, $5 \mathrm{HT}_{3}$ receptors), or $\mathrm{G}$ protein-coupled receptors (for example, $5 \mathrm{HT}_{1}, 5 \mathrm{HT}_{2}$, and $5 \mathrm{HT}_{4-7}$ receptors) $[6,28]$

Both peripheral and central nervous systems have serotonin receptors. This neurotransmitter system has numerous effects on either cardiovascular or gastrointestinal systems, can regulate temperature and determines affective disorders. Apart from these, its involvement in memory processes has been studied throughout time $[6,14,17]$.

Ever since 1990, when Barnes determined that the serotoninergic system [5] (using the 5- $\mathrm{HT}_{3}$ receptors) conditions cognition improvements in young and aged rats, it has been suggested in literature that all the serotoninergic receptors are more or less associated with cognitive functions (Table I).

The importance of $5-\mathrm{HT}_{1}$ receptor type has been controversial over the time. While some studies determined that receptor agonists (for example, 8$\mathrm{OH}-\mathrm{DPAT}$ and buspirone) disrupt learning and memory processes $[53,62]$, improvement in cognitive function has been reported after the use of receptor agonists, such as MDL $73005[8,54]$. However, most of the studies in literature conclude that by activating the $5-\mathrm{HT}_{1}$ receptors, serotonin has a negative effect in cognition.

The antagonists of the $5-\mathrm{HT}_{2 \mathrm{~A}}$ receptors can be involved in certain cognitive processes as well. One study performed in 2003 showed that the visualspatial attention can be improved by injecting these antagonists. The same substances have been shown to decrease impulsivity in the rat 5-choice serial reaction time task after injecting the selective 5$\mathrm{HT}_{2 \mathrm{~A}}$ receptor antagonist MDL 100907 [83]. However, ketanserin (a 5- $\mathrm{HT}_{2 \mathrm{~A}}$ antagonist) did not improve the memory in the radial arm maze, neither did it increase operant signal detection task in rats [39].

Speaking about $5-\mathrm{HT}_{3}$ receptors, their antagonists (in example, SEC 579, DAU 6215, ondansetron, granisetron, and WAY 100579, RS-56812) are capable to reverse pharmacologically-induced cognitive impairments as well as produce stand-alone memory enhancement $[5,13,23,30,66,67]$. However, different trials were not able to demonstrate the beneficial effects on cognition of 5-HT3 receptor antagonists [59].

While speaking about $5-\mathrm{HT}_{4}$ receptors, it has been found that by activating the adenylate cyclase, they increase the intracellular levels of cAMP, an important component in synaptic long-term potentiation [25]. In order to improve cognitive processes in animal models, $5-\mathrm{HT}_{4}$ receptor agonists can be used $[35,52]$. Aside from this, we can safely say that selective 5HT4 receptor antagonists can be used to reverse the beneficial effects of the $5-\mathrm{HT}_{4}$ receptor agonists on memory, highlighting the involvement of these receptors in cognitive processes [24, 37, 57].

Initially, the role of $5-\mathrm{HT}_{6}$ receptors in cognitive processes has been supported by the fact that receptor knock-down improved retention in the water maze task in normal rats [7, 84]. By administering serotonin antagonists, studies have been able to show the significance of this receptor blockade, which can be used for consolidation processes, but not for improving learning performance in normal adult rats [47, 71, $77,84]$. On the other hand, in aged rats, some studies concluded that the antagonists of the $5-\mathrm{HT}_{6}$ receptors are able to enhance both retention performance and acquisition learning [22, 29, 77].

The $5-\mathrm{HT}_{7}$ receptor is one of the most recently described members of the serotonin receptor family. Functionally, this receptor is associated with a number of physiological and pathological responses, including the circadian rhythm, control of memory, as well as locomotor and exploratory activity. During the last decade, several selective agonists and antagonists for $5-\mathrm{HT}_{7}$ receptors have been developed and studied, in order to determine the role of these receptors, but further studies need to be performed in order to reach a conclusion.

It has been found that serotonin also participates in the formation of receptor complexes. Levin reported that antagonists of 5- $\mathrm{HT}_{2}$ influence nicotine's functions. For example, ketanserin reduced nicotine's enhancing effects on attention and working memory [38].

The relationship between the $5-\mathrm{HT}_{4}$ receptors and the nicotinic system has been proven in literature as well. That is to say that agonists of $5-\mathrm{HT}_{4}$ receptors have synergistic effects with cholinesterase inhibitors (for example rivastigmine, donepezil and galanthamine), which has been described in animal models of cognition $[11,56,57]$.

The ability of $5-\mathrm{HT}_{6}$ receptors to increase the release of acetylcholine in brain regions involved in learning and memory processes has been suggested as the cause of some of the serotonin positive effects on cognition in young and aged animals $[29,69,76,87]$. 
Table I

Receptor subtypes for the adrenergic, serotoninergic, dopaminergic and glutamate systems and their use in memory modulation

\begin{tabular}{|c|c|c|c|c|c|}
\hline System & $\begin{array}{c}\text { Receptor } \\
\text { subtype }\end{array}$ & $\begin{array}{c}\text { Receptor } \\
\text { Activation }\end{array}$ & Cognition Effects & System Association & $\begin{array}{c}\text { Association's } \\
\text { effects on cognition }\end{array}$ \\
\hline \multirow{10}{*}{ Adrenergic } & \multirow{2}{*}{$\alpha_{1}$} & Agonists & + & \multirow{10}{*}{ Nicotine } & \multirow{10}{*}{ Stimulation } \\
\hline & & Antagonists & - & & \\
\hline & \multirow{2}{*}{$\alpha_{2}$} & Agonists & + & & \\
\hline & & Antagonists & - & & \\
\hline & \multirow{2}{*}{$\beta_{1}$} & Agonists & - & & \\
\hline & & Antagonists & + & & \\
\hline & \multirow{2}{*}{$\boldsymbol{\beta}_{2}$} & Agonists & + & & \\
\hline & & Antagonists & - & & \\
\hline & \multirow[b]{2}{*}{$\boldsymbol{\beta}_{3}$} & Agonists & + & & \\
\hline & & Antagonists & - & & \\
\hline \multirow{2}{*}{ Glutamate } & \multirow{2}{*}{ NMDA } & Agonists & + & \multirow{2}{*}{ Nicotine } & \multirow{2}{*}{ Stimulation } \\
\hline & & Antagonists & - & & \\
\hline \multirow{10}{*}{ Dopaminergic } & \multirow{2}{*}{$\mathbf{D}_{1}$} & Agonist & + & \multirow{10}{*}{ Nicotine } & \multirow{10}{*}{$\begin{array}{l}\mathrm{N} \longrightarrow \mathrm{D} \\
\mathrm{D} \stackrel{+--}{\longrightarrow} \mathrm{N}\end{array}$} \\
\hline & & Antagonist & - & & \\
\hline & \multirow{2}{*}{$D_{5}$} & Agonist & + & & \\
\hline & & Antagonist & - & & \\
\hline & \multirow{2}{*}{$\mathbf{D}_{2}$} & Agonist & + & & \\
\hline & & Antagonist & - & & \\
\hline & \multirow{2}{*}{$\mathbf{D}_{3}$} & Agonist & - & & \\
\hline & & Antagonist & + & & \\
\hline & \multirow{2}{*}{$\mathbf{D}_{4}$} & Agonist & - & & \\
\hline & & Antagonist & + & & \\
\hline \multirow{28}{*}{ Serotoninergic } & & Agonist & - & & \\
\hline & $5-\mathrm{HT}_{1}$ & Antagonist & + & & \\
\hline & & Agonist & - & & \\
\hline & $5-\mathrm{HI}_{1 \mathrm{~B}}$ & Antagonist & + & & \\
\hline & 5-HT & Agonist & No effect & $\mathrm{No}$ & No \\
\hline & $5-H I_{1 D}$ & Antagonist & No effect & No & No \\
\hline & $5-\mathrm{HT}_{1}$ & Agonist & No effect & & \\
\hline & $5-H_{1 E}$ & Antagonist & No effect & & \\
\hline & & Agonist & No effect & & \\
\hline & $5-\mathrm{HT}_{1 \mathrm{~F}}$ & Antagonist & No effect & & \\
\hline & 5-HT & Agonist & - & Nicotine & Stimulation \\
\hline & $3-\mathrm{HI}_{2 \mathrm{~A}}$ & Antagonist & + & & \\
\hline & & Agonist & No effect & & \\
\hline & $5-\mathrm{HT}_{2 \mathrm{~B}}$ & Antagonist & No effect & No & $N$ \\
\hline & 5.HT & Agonist & No effect & No & No \\
\hline & $-\mathrm{SH}_{2 \mathrm{C}}$ & Antagonist & No effect & & \\
\hline & 5-HT, & Agonist & $-(?)$ & No & No \\
\hline & $5-\mathrm{HT}_{3}$ & Antagonist & $+(?)$ & No & \\
\hline & 5-HT & Agonist & + & Nicotine & Stimulation \\
\hline & 5-HI & Antagonist & - & Nicotine & Stimulation \\
\hline & 5-HT & Agonist & No effect & & \\
\hline & $5-H I_{5 A}$ & Antagonist & No effect & & \\
\hline & & Agonist & $\begin{array}{c}\text { Not seen in } \\
\text { humans }\end{array}$ & No & No \\
\hline & $5-\mathrm{HT}_{5 \mathrm{~B}}$ & Antagonist & $\begin{array}{l}\text { Not seen in } \\
\text { humans }\end{array}$ & & \\
\hline & 5-HT & Agonist & - & Nicotine & Stimulation \\
\hline & $3-\mathrm{HI}_{6}$ & Antagonist & + & Nicotine & Stimulation \\
\hline & $5_{-} \mathrm{HT}_{-}$ & Agonist & (?) & $\mathrm{No}$ & No \\
\hline & $5-\mathrm{HT}_{7}$ & Antagonist & (?) & No & No \\
\hline
\end{tabular}


FARMACIA, 2019, Vol. 67, 2

In the past few years, scientists have tried to determine if these observations made on animals, are appropriate for humans as well. That is why a number of studies have determined the role of the serotoninergic system in a number of health issues that involve cognitive dysfunctions, such as schizophrenia, Alzheimer's disease and others.

It is a well-known fact, that schizophrenia determines a degree of cognitive impairment. This has previously been assigned to the loss of certain nicotinic receptors (alpha-7 and alpha-4-beta-2). However studies have showed that the serotoninergic system might be involved as well in these processes. For example, one study identified the action of a selective $5-\mathrm{HT}_{2}$ antagonist (namely, ketanserin) of neutralizing the cognitive enhancement induced by the nicotinic system [37]. However, Roth concluded in 2004 that the use $5-\mathrm{HT}_{2 \mathrm{~A}}$ receptor antagonists (such as mianserin and MDL 100, 907) in patients with schizophrenia can have modest effects on cognition [71]. Moreover, even though ondansetron did not show any effect in an AD clinical trial [19], there has been an interest in using this substance for the cognitive dysfunctions associated with schizophrenia $[2,88]$. Considering Alzheimer's disease, lecozotan (SRA333), which is a 5-HT1A receptor antagonist, was safe and well tolerated in a clinical trial performed in both healthy young and elderly subjects [65]. Speaking about a clinical phase II trial in patients with mild to moderate Alzheimer's disease, the same substance has been injected, although the outcome hasn't been reported [75]. By activating the 5-HT4 receptors, we can alleviate symptoms, as well as induce secretion of the soluble form of amyloid precursor protein ( $\mathrm{SAPP} \alpha)$, an effect seen in vitro [33, 42, 70]. Meanwhile, in vivo, the agonists of the 5-HT4 receptors increased sAPP $\alpha$ levels in both the hippocampus and the cortex in young adult and transgenic APP-overexpressing mice [11].

\section{Conclusions}

Memory is an elaborate and intricate cognitive function. There is no doubt that learning and memory are, of course, derived from experience-induced changes in behaviour. Moreover, there is now extensive evidence that administration of central nervous system stimulants enhance memory when administered shortly after training.

Nicotine is one of the main substances associated with both learning and memory. The prevailing theory published in literature postulates that nicotine has an enhancing effect on cognition. Its effects can be either direct, or exerted in an indirect manner, by forming receptor complexes. Literature certifies that other neurotransmitters and systems, which can be associated with certain memory processes as well, are the dopaminergic system, the NMDA receptors, the serotoninergic receptors, and even the adrenergic receptors.

\section{References}

1. Ahmadi S, Zarrindast MR, Nouri M, Haeri-Rohani A, Rezayof A, N-Methyl-D-aspartate receptors in the ventral tegmental area are involved in retrieval of inhibitory avoidance memory by nicotine. Neurobiol Learn Memory, 2007; 88: 352-358.

2. Akhondzadeh S, Mohammadi N, Noroozian M, Karamghadiri N, Ghoreishi A, Jamshidi AH, Added ondansetron for stable schizophrenia: a double blind, placebo controlled trial. Schizophr Res., 2009; 107: 206-212.

3. Arnsten AF, Goldman-Rakic PS, Alpha 2-adrenergic mechanisms in prefrontal cortex associated with cognitive decline in aged nonhuman primates. Science, 1985; 230(4731): 1273-1276.

4. Azizbeigi R, Ahmadi S, Babapour V, Rezayof A, Zarrindast MR, Nicotine restores morphine-induced memory deficit through the D1 and D2 dopamine receptor mechanisms in the nucleus accumbens. $J$ Psychopharmac., 2011; 25(8): 1126-1133.

5. Barnes JM, Costall B, Coughlan J, Domeney AM, Gerrard PA, Kelly ME, The effects of ondansetron, a 5-HT3 receptor antagonist, on cognition in rodents and primates. Pharmacol Biochem Behav., 1990; 35: 955-962.

6. Barnes NM, Sharp TA, A review of central 5-HT receptors and their function. Neuropharmacology, 1999; 38: 1083-1152.

7. Bentley J, Sleight AJ, Marsden CA, Fone KCF, 5HT6 antisense oligonucleotide i.c.v. affects rat performance in the water maze and feeding. $J$ Psychopharmacol., 1997; 11: A64.

8. Bertrand F, Lehmann O, Galani R, Lazarus C, Jeltsch H, Cassel JC, Effects of MDL 73005 on watermaze performances and locomotor activity in scopolamine-treated rats. Pharmacol Biochem Behav., 2001; 68: 647-660.

9. Bhardwaj SK, Tse YC, Ryan R, Wong TP, Srivastava LK, Impaired adrenergic-mediated plasticity of prefrontal cortical glutamate synapses in rats with developmental disruption of the ventral hippocampus. Neuropsychopharmacology, 2014; 39(13): 2963-2973.

10. Blake MG, Krawczyk MC, Baratti CM, Boccia MM, Neuropharmacology of memory consolidation and reconsolidation: Insights on central cholinergic mechanisms. J Physiol Paris, 2014; 108(4-6): 286-289.

11. Cachard-Chastel M, Devers S, Sicsic S, Langlois M, Lezoualc'h F, Gardier AM, Belzung C, Prucalopride and donepezil act synergistically to reverse scopolamineinduced memory deficit in C57BL/6j mice. Behav Brain Res., 2008; 187: 455-461.

12. Camp RM, Johnson JD, Repeated stressor exposure enhances contextual fear memory in a beta-adrenergic receptordependent process and increases impulsivity in a non-beta receptor-dependent fashion. Physiol Behav., 2015; 150: 64-68.

13. Carli M, Lushi R, Sammanin R, Dose related impairments of spatial learning by intrahippocampal scopolamine and antagonism by ondansetron, a 5- 
FARMACIA, 2019, Vol. 67, 2

HT3 receptor antagonist. Behav Brain Res., 1997; 82: 185-194.

14. Cassel JC, Jeltsch H, Serotonergic modulation of cholinergic function in the central nervous system: cognitive implications. Neuroscience, 1995; 69: 1-41.

15. Chen S, Liu F, Interaction of dopamine D1 receptor with $\mathrm{N}$-ethylmaleimide-sensitive factor is important for the membrane localization of the receptor. $J$ Neurosci Res., 2010; 88: 2504-2512.

16. Chirila M, Ghita I, Fulga I, Current knowledge on brupropion and varenicline clinical efficacy in nicotine dependence. Farmacia, 2015; 63(1): 1-7.

17. Cong L, Jiao Y, Dong Y, The effect of lamotrigine monotherapy after conversion from the combined therapy lamotrigine and valproic acid in patients with epilepsy. Farmacia, 2017; 65(6): 885-890.

18. Decamp E, Schneider JS, Interaction between nicotinic and dopaminergic therapies on cognition in a chronic parkinson model. Brain Res., 2009; 1262: 109-114.

19. Dysken M, Kuskowski M, Love S, Ondansetron in the treatment of cognitive decline in Alzheimer's dementia. Am J Geriatr Psychiatry, 2002; 10: 212-215.

20. Ferry B, McGaugh JL, Role of amygdala norepinephrine in mediating stress hormone regulation of memory storage. Acta Pharmacol Sin., 2000; 21(6): 481-493.

21. Fitzgerald MK, Otis JM, Mueller D, Dissociation of $\beta 1$ - and $\beta 2$-adrenergic receptor subtypes in the retrieval of cocaine-associated memory. Behav Brain Res., 2016; 296: 94-99.

22. Foley AG, Murphy KJ, Hirst WD, Gallagher HC, Hagan JJ, Upton N, The 5-HT6 receptor antagonist SB-271046 reverses scopolamine-disrupted consolidation of a passive avoidance task and ameliorates spatial task deficits in aged rats. Neuropsychopharmac., 2004; 29: 58-67.

23. Fontana DJ, Daniels SE, Henderson C, Eglen RM, Wong EH, Ondansetron improves cognitive performance in the Morris water maze spatial navigation task. Psychopharmacology, 1995; 120: 408-417.

24. Fontana DJ, Daniels SE, Wong EH, Clark RD, Eglen RM, The effects of novel, selective 5-hydroxytryptamine (5-HT)4 receptor ligands in rat spatial navigation. Neuropharmacology, 1997; 36: 689-696.

25. Frey U, Huang YY, Kandel ER, Effects of cAMP simulate a late stage of LTP in hippocampal CA1 neurons. Science, 1993; 260: 1661-1664.

26. Fulginiti S, Molina VA, Orsingher OA, Inhibition of catecholamine biosynthesis and memory processes. Psychopharmacology, 1976; 51: 65-69.

27. Greenamyre JT, Maragos WF, Albin RL, Penney $\mathrm{JB}$, Young AB, Glutamate transmission and toxicity in Alzheimer's disease. Prog Neuro-Psychopharmoc Biol Psychiat., 1988; 12: 421-430

28. Hannon J, Hoyer D, Molecular biology of 5-HT receptors. Behav Brain Res., 2008; 195: 198-213.

29. Hirst WD, Stean TO, Rogers DC, Sunter D, Pugh P, Moss SF, Bromidge SM, Riley G, Smith DR, Bartlett S, Heidbreder CA, Atkins AR, Lacroix LP, Dawson LA, Foley AG, Regan CM, Upton N, SB399885 is a potent, selective 5-HT6 receptor antagonist with cognitive enhancing properties in aged rat water maze and novel object recognition models. Eur J Pharmacol., 2006; 553: 109-119.
30. Hodges H, Sowinski P, Sinden JD, Netto CA, Fletcher A, The selective 5HT3 antagonist, WAY100289 , enhances spatial memory in rats with ibotenate lesions of the forebrain cholinergic projection system. Psychopharmacology, 1995; 117: 318-332.

31. Horrigan JP, Barnhill LJ, Guanfacine for treatment of attention-deficit hyperactivity disorder in boys. $J$ Child Adolesc Psychopharmac., 1995; 5(3): 215-223.

32. Hunt RD, Arnsten AF, Asbell MD, An open trial of guanfacine in the treatment of attention-deficit hyperactivity disorder. J Am Acad Child Adolesc Psychiatry, 1995; 34(1): 50-54.

33. Iova A, Micle O, Vicaș L, Micle L, Iova S, Mureşan M, Ioniță CA, Oxidative stress in Alzheimer's dementia. Farmacia, 2014; 62(3): 546-554.

34. Kim JS, Levin ED, Nicotinic, muscarinic and dopaminergic actions in the ventral hippocampus and the nucleus accumbens: effects on spatial working memory in rats. Brain Res., 1996; 725: 231-240.

35. King MV, Marsden CA, Fone KCF, A role for the 5-HT1A, 5-HT4 and 5-HT6 receptors in learning and memory. Trends Pharmacol Sci., 2008; 29: 482-492.

36. Komal P, Estakhr J, Kamran M, Renda A, Nashmi R, cAMP-dependent protein kinase inhibits $\alpha 7$ nicotinic receptor activity in layer 1 cortical interneurons through activation of D1/D5 dopamine receptors. $J$ Physiol., 2015; 593(16): 3513-3532.

37. Lamirault L, Simon H, Enhancement of place and object recognition memory in young adult and old rats by RS 67333, a partial agonist of 5-HT4 receptors. Neuropharmacology, 2001; 41: 844-853.

38. Levin E, Icenogle L, Farzad A, Ketanserin attenuates nicotine-induced working memory improvement in rats. Pharmacol Biochem Behav., 2005; 82: 289-292.

39. Levin ED, Rezvani AH, Nicotinic interactions with antipsychotic drugs, models of schizophrenia and impacts on cognitive function. Biochem Pharmac., 2007; 74: 1182-1191.

40. Levin ED, Sledge D, Baruah A, Addy NA, Ventral hippocampal NMDA blockade and nicotinic effects on memory function. Brain Res Bull., 2003; 61: 489-495.

41. Lupuşoru CE, Popa EG, Sandu RB, Buca BR, Mititelu-Tarțău L, Lupușoru RV, The influence of Bidens tripartita extracts on psychomotor abilities and cognitive functions in rats. Farmacia, 2017; 65(2): 284-288.

42. Lezoualc'h F, 5-HT4 receptor and Alzheimer's disease: the amyloid connection. Exper Neurol., 2007; 205: 325-329.

43. Li BM, Mei ZT, Delayed response deficit induced by local injection of $\alpha 2$-adrenergic antagonist yohimbine into the dorsolateral prefrontal cortex in young adult moneys. Behav Neural Biol., 1994; 62: 134-139.

44. Li S, Nai Q, Lipina TV, Roder JC, Liu F, $\alpha 7 n A c h R /$ NMDAR coupling affects NMDAR function and object recognition. Mol Brain, 2013, 6: 1-10.

45. Long C, Chen MF, Sarwinski SJ, Chen PY, Si M, Hoffer BJ, Evans MS, Lee TJF, Monoamine uptake inhibitors block 7-nAChR-mediated cerebral nitrergic neurogenic vasodilation. Am J Physiol Heart Circ Physiol, 2006; 291: H202-H209.

46. Luo F, Guo N, Zheng J, Cheng Z, Li B, $\beta 1$-and $\beta 2$ adrenoceptors in hippocampal CA3 region are required 
FARMACIA, 2019, Vol. 67, 2

for long-term memory consolidation in rats. Brain Res., 2015; 1627: 109-118.

47. Marcos B, Chuang TT, Gil-Bea FJ, Ramirez MJ, Effects of 5-HT6 receptor antagonism and cholinesterase inhibition in models of cognitive impairment in the rat. Brit J Pharmacol., 2008; 155: 434-440.

48. Markett S, Montag C, Walter NT, Reuter M, Evidence for the modality independence of the genetic epistasis between the dopaminergic and cholinergic system on working memory capacity. Eur Neuropsychopharmac.., 2011; 21: 216-220.

49. Markett S, Reuter M, Montag C, Weber B, The dopamine $\mathrm{D} 2$ receptor gene DRD2 and the nicotinic acetylcholine receptor gene CHRNA4 interact on striatal gray matter volume: Evidence from a genetic imaging study. Neuro Image, 2013; 64: 167-172.

50. Martorana A, Koch G, Is dopamine involved in Alzheimer's disease?. Front Aging Neurosci., 2014; 6: $1-6$

51. May-Simera H, Levin ED, NMDA systems in the amygdala and piriform cortex and nicotinic effects on memory function. Cogn Brain Res., 2003; 17: 475-483.

52. Meneses A, 5-HT system and cognition. Neurosci Biobehav Rev., 1999; 23: 1111-1125.

53. Meneses A, Perez-Garcia G, 5-HT(1A) receptors and memory. Neurosci Biobehav Rev., 2007; 31: 705-727.

54. Millan MJ, Gobert A, Roux S, Porsolt R, Meneses A, Carli M, The serotonin1A receptor partial agonist S15535 [4-(benzodioxan-5yl)1-(indan-2-yl)piperazine] enhances cholinergic transmission and cognitive function in rodents:a combined neurochemcial and behavioral analysis. J Pharmacol Exp Ther., 2004; 311: 190-203.

55. Missale C, Nash SR, Robinson SW, Jaber M, Caron MG, Dopamine receptors: From structure to function. Physiolog Rev., 1998; 78 (1): 189-225.

56. Mohler EG, Shacham S, Noiman S, Lezoualc'h F, Robert S, Gastineau M, Rutkowski J, Marantz Y, Dumuis A, Bockaert J, Gold PE, Ragozzino ME, VRX-03011, a novel 5-HT4 agonist, enhances memory and hippocampal acetylcholine efflux. Neuropharmac., 2007; 53: 563-573.

57. Moser PC, Bergis OE, Jegham S, Lochead A, Duconseille E, Terranova JP, Caille D, BerqueBestel I, Lezoualc'h F, Fischmeister R, Dumuis A, Bockaert J, George P, Soubrié P, Scatton B, SL65.0155, a novel 5-hydroxytryptamine4 receptor partial agonist with potent cognition-enhancing properties. J Pharmacol Exp Ther., 2002; 302: 731-741.

58. Mundy WR, Iwamoto ET, Nicotine impairs acquisition of radial maze performance in rats. Pharmac Biochem Behav., 1988; 30: 119-122.

59. Naghdi N, Harooni HE, The effect of intrahippocampal injections of ritanserin (5-HT2A/2C antagonist) and granisetron (5-HT3 antagonist) on learning as assessed in the spatial version of the water maze. Behav Brain Res., 2005; 157: 205-210.

60. Narahashi T, Moriguchi S, Zhao X, Marszalec W, Yeh JZ, Mechanisms of action of cognitive enhancers on neuroreceptors. Biol Pharm Bull., 2004; 27(11): 1701-1706.
61. Norozpour Y, Nasehi M, Sabouri-Khanghah V, Torabi-Nami M, Zarrindast MR, The effect of CA1 $\alpha 2$ adrenergic receptors on memory retention deficit induced by total sleep deprivation and the reversal of circadian rhythm in a rat model. Neurobiol Learn Mem., 2016; 133: 53-60.

62. Ogren SO, Eriksson TM, Elvander-Tottie E, D'Addario C, Ekström JC, Svenningsson P, Meister B, Kehr J, Stiedl O, The role of 5-HT1A receptors in learning and memory. Behav Brain Res., 2008; 195: 54-77.

63. Okada H, Ouchi Y, Ogawa M, Futatsubashi M, Saito Y, Yoshikawa E, Terada T, Oboshi Y, Tsukada H, Ueki T, Watanabe M, Yamashita T, Magata Y, Alterations in $\mathrm{a} 4 \mathrm{~b} 2$ nicotinic receptors in cognitive decline in Alzheimer's etiopathology. Brain, 2013; 136: 3004-3017

64. Otis JM, Fitzgerald MK, Mueller D, Inhibition of hippocampal b-Adrenergic receptors impairs retrieval but not reconsolidation of cocaine-associated memory and prevents subsequent reinstatement. Neuropsychopharmac., 2014; 39: 303-310.

65. Patat A, Parks V, Raje S, Plotka A, Chassard D, Coz FL, Safety, tolerability, pharmacokinetics and pharmacodynamics of ascending single and multiple doses of lecozotan in healthy young and elderly subjects. Brit J Clin Pharmacol., 2008; 67: 299-308.

66. Pitsikas N, Borsini F, Itasetron (DAU 6215) prevents age-related memory deficits in the rat in a multiple choice avoidance task. Eur J Pharmac., 1996; 311 : 115-119.

67. Pitsikas N, Bramibilla A, Borsini F, DAU 6215, a novel 5-HT3 receptor antagonist, improves performance in the aged rat in the Morris water maze task. Neurobiol Aging., 1993; 14: 561-564.

68. Puma C, Deschaux O, Molimard R, Bizot JC, Nicotine improves memory in an object recognition task in rats. Eur Neuropsychopharmacol., 1999; 9: 323-327.

69. Riemer C, Borroni E, Levet-Trafit B, Martin JR, Poli $\mathrm{S}$, Porter RHP, Influence of the 5-HT6 receptor on acetylcholine release in the cortex: pharmacological characterization of 4-(2-bromo-6-pyrrolidin-1-ylpyridine-4-sulfonyl) phenylamine, a potent, selective 5-HT6 receptor antagonist. J Med Chem., 2003; 46: 1273-1276.

70. Robert SJ, Zugaza JL, Fischmeister R, Gardier AM, Lezoualc'h F, The human serotonin 5-HT4 receptor regulates secretion of non-amyloidogenic precursor protein. J Biol Chem., 2001; 276: 44881-44888.

71. Rogers DC, Hagan JJ, 5-HT6 receptor antagonists enhance retention of a water-maze task in the rat. Psychopharmacology, 2001; 158: 114-119.

72. Roozendaal B, McGaugh JL, Memory modulation. Behav Neurosci., 2011; 125(6): 797-824.

73. Roth BL, Hanizavareh SM, Blum AE, Serotonin receptors represent highly favorable molecular targets for cognitive enhancement in schizophrenia and other disorders. Pyschopharmacology, 2004; 174: 17-24.

74. Ruotsalainen S, Miettinen R, Macdonald E, Riekkinen $\mathrm{M}$, Sirvio J, The role of the dorsal raphe-serotonergic system and cholinergic receptors in the modulation of working memory. Neurosci Biobehav Rev., 1998; 22(1): 21-31. 
FARMACIA, 2019, Vol. 67, 2

75. Sabbagh MN, Drug development for Alzheimer's disease: where are we now and where are we headed?. Am J Geriatr Pharm., 2009; 7: 167-185.

76. Shirazi-Southall S, Rodriguez DE, Nomikos GG, Effects of typical and atypical antipsychotoics and receptor selective compounds on acetylcholine efflux in the hippocampus of the rat. Neuropsychopharmac., 2002; 26: 583-594.

77. Stean TO, Hirst WD, Thomas DR, Price GW, Rogers D, Riley G, Bromidge SM, Serafinowska HT, Smith DR, Bartlett S, Deeks N, Duxon M, Upton N, Pharmacological profile of SB-357134: a potent, selective brain penetrant, and orally active 5-HT(6) receptor antagonist. Pharmac Biochem Behav., 2002; 71: 645-654.

78. Strosberg AD, Structure, function, and regulation of adrenergic receptors. Protein Science, 1993; 2: 1198-1209.

79. Sydserff S, Sutton EJ, Song D, Quirk MC, Maciag C, Li C, Jonak G, Gurley D, Gordon JC, Christian EP, Doherty JJ, Hudzik T, Johnson E, Mrzljak L, Piser T, Smagin GN, Wang Y, Widzowski D, Smith JS, Selective a7 nicotinic receptor activation by AZD0328 enhances cortical dopamine release and improves learning and attentional processes. Biochem Pharmac., 2009; 78: 880-888.

80. Torkaman-Boutorabi A, Sheidadoust H, HashemiHezaveh SM, Zarrindast MR, Influence of morphine on medial prefrontal cortex alpha2 adrenergic system in passive avoidance learning in rats. Pharmac Biochem Behav., 2015; 133: 92-98.

81. Vyklicky V, Korinek M, Smejkalova T, Balik A, Krausova B, Kaniakova M, Lichnerova K, Cerny J, Krusek J, Dittert I, Horak M, Vyklicky L, Structure, function, and pharmacology of NMDA receptor channels. Physiol Res., 2014; 63(Suppl.1): S191-S203.
82. Wei SG, Li XW, Differential effects of propranolol on conditioned hyperactivity and locomotor sensitization induced by morphine in rats. Sci Rep., 2014; 4: 1-7.

83. Winstanley CA, Chudasama Y, Dalley JW, Theobald DEH, Glennon JC, Robbins TW, Intra-prefrontal 8OH-DPAT and M100907 improve visuospatial attention and decrease impulsivity on the five choice serial reaction time task in rats. Psychopharmacology, 2003; 167: 304-314.

84. Woolley ML, Bentley JC, Sleight AJ, Mardsen CA, Fone $\mathrm{KCF}$, A role for $5-\mathrm{Ht}(6)$ receptors in retention of spatial learning in the Morris water maze. Neuropharmacology, 2001; 41: 210-219.

85. Yamazaki Y, Jia Y, Niu R, Sumikawa K, Nicotine exposure in vivo induces long-lasting enhancement of NMDA receptor-mediated currents in the hippocampus. Eu J Neurosci., 2006; 23: 1819-1828.

86. Yuan Q, Shakhawat A, Harley CW, Mechanisms underlying early odor preference learning in rats. Prog Brain Res., 2014; 208: 115-156.

87. Zhang M-Y, Hughes ZA, Kerns EH, Lin Q, Beyer $\mathrm{CE}$, Development of a liquid chromatography/tandem mass spectrometry method for the quantitation of acetylcholine and related neurotransmitters in brain microdialysis samples. J Pharm Biomed Anal., 2007; 44: 586-593.

88. Zhang ZJ, Kang WH, Li Q, Wang XY, Yao SM, Ma $\mathrm{AQ}$, Beneficial effects of ondansetron as an adjunct to haloperidol for chronic, treatment-resistant schizophrenia: a double-blind, randomized, placebo-controlled study. Schizophr Res., 2006; 88: 102-110.

89. Zinn CG, Clairisb N, Cavalcantea LES, Furinia CRG, Myskiwa JC, Izquierdo I, Major neurotransmitter systems in dorsal hippocampus and basolateral amygdala control social recognition memory. PNAS, 2016; 113(33): E4914-E4919. 